\title{
Preservice Chemistry Teachers' Epistemic Beliefs After a Student-Centred Approach Training Programme
}

\author{
Luisa López-Banet ${ }^{1 *}$, Marina Martínez-Carmona ${ }^{1}$ \\ 1 University of Murcia, SPAIN
}

Received 14 August 2021 - Accepted 6 November 2021

\begin{abstract}
Recent studies in science education have recognized a possible link between teachers' beliefs about scientific knowledge and its practice in the classroom. Therefore, it is essential to promote the evolution of the pre-service teachers' initial beliefs about methodologies for the teaching of chemistry in accordance with the discipline foundations and current recommendations on science teaching. We present the implementation and evaluation of a sequence of activities with a student-centred teaching approach for the training of pre-service science secondary education teachers. Inquiry, modelling, argumentation, as well as game-based learning are examples of the methodologies used. The results show a change of orientation from the epistemic beliefs prior to the programme implementation and highlight significant differences with respect to the relevance given by the teachers to carrying out research activities. For future teachers to develop professional competence, it is necessary to offer them opportunities to experience alternative methodologies during their training.
\end{abstract}

Keywords: beliefs, methods, scientific competence, scientific practices, secondary education, teacher training

\section{INTRODUCTION}

Recent studies have shown a gap between the results of educational research on science teaching and what is transferred to the classroom (Martínez-Chico et al., 2014). It is therefore necessary to reorient teacher training programmes and to propose reference frameworks for the acquisition of teaching skills that allow teaching tasks to be carried out in accordance with current approaches on the construction of scientific knowledge. Numerous contributions in the field of scientific education highlight the importance of teaching how to 'do science' in the classroom and involving students in activities related to manipulative, communicative and cognitive skills, in line with the school level (Jaber \& Hammer, 2016). Scientific content must be connected with technological and scientific practices and skills, without forgetting personal and social perspectives (Talanquer, 2013). In this sense, scientific practices play a relevant role in current science teaching, and various investigations support activities aimed at fostering argumentation among students in the face of socio-scientific issues (Christenson \& Chang, 2014; López-Banet et al., 2020; Zidny et al., 2021) or model-based inquiry (MBI) approaches to teaching (Jiménez-Liso et al., 2018). Despite the previous results, the usual methodology used in the teaching of chemistry, as well as the basic content selected as the reference, remains practically intact (Talanquer, 2013), so the teaching of chemistry must be approached from a new perspective. For this reason, specific teacher training is necessary to offer resources to promote student participation in scientific practices (Crujeiras \& Jiménez, 2018). Teaching activities related to the history of science can be useful for improving implicit and explicit knowledge of what science is and how it is built (Jiménez-Liso et al., 2020b). The use of this resource during teacher training can improve the understanding of the nature of science and allow future teachers to know and assimilate adequate resources with which to introduce this content into their own classroom in a holistic way (Acevedo-Díaz et al., 2017). Likewise, methodologies such as game-based learning are increasingly found among researchers and educators because of their potential to promote motivation and

(c) 2021 by the authors; licensee Modestum. This article is an open access article distributed under the terms and conditions of the Creative Commons Attribution License (http://creativecommons.org/licenses/by/4.0/).

\Ilopezbanet@um.es (*Correspondence) $\square$ marina.m.c1@um.es 


\section{Contribution to the literature}

- To describe a teacher training programme with the aim to promote preservice teacher reflection about student-centred approaches based on scientific practices, such as inquiry, modelling, argumentation, and game-based learning.

- To analyse the evolution of the epistemic beliefs regarding teaching chemistry held by preservice teachers after the implementation of the training programme.

- To evaluate the concordance between the beliefs expressed by the preservice teachers and what they put into practice in their teaching units.

interest in science (Annetta et al., 2014; Franco \& Oliva, 2013). Educational games are greatly valued by students and have been shown to produce significant progress in learning the content (Franco \& Oliva, 2013). However, this playful approach, based on motivation, has a much greater scope, being able to promote not only conceptual but scientific content. It is important to differentiate between using the game just to "make the class more entertaining" or "to learn to do better science" (López \& Domenech-Casal, 2018). For instance, Vázquez-Alonso and Manassero-Mas (2016) published an article in which proposed a simple series of games through which students acquired skills related to the nature of scientific and technological knowledge.

\section{Teacher Training}

It is evident that teachers, during teaching, should not focus exclusively on content knowledge, but should also incorporate procedural and epistemic knowledge, to promote a scientific understanding of phenomena and their correct interpretation (Bellová et al., 2017). The understanding of the nature of chemistry affects the type of instructional activities utilized by high school chemistry teachers. As a consequence, student learning might depend on who their teacher was, in spite of having to implement the same chemistry curriculum as others (Lantz \& Kass, 1987). In chemistry lessons, students used to be expected to accept the knowledge elaborated by the teachers, taken as an unquestionable dogma and promoting an unfounded final thought form. Nevertheless, a different scenario could encourage students to understand what a claim is, why it should be believed in, and how it is justified by evidence, distinguishing those that are reliable from those that are not. In this second scenario, the teacher is engaging the students in the assessment of knowledge (Erduran \& Kaya, 2019). Moreover, conceptions influenced by traditional practices, such as a lack of participation by students in establishing their own scientific ideas or excessive control by the teacher in the accomplishment of the task rather than the understanding of it, represent a limiting factor in the implementation of scientific practices. Therefore, improving teachers' understanding could encourage greater inclusion in science classes (Donnelly et al., 2014).
Studies regarding student teachers' beliefs about teaching and learning science have shown that physics and chemistry teachers in training often opt for teaching approaches centred more on the teacher and the content, although chemistry teachers are less reluctant. Preservice teachers (PSTs) of other science subjects such as biology usually appear to be more open and studentoriented (Markic et al., 2008). In addition, open-ended activities of this type tend to present more difficulties for students than traditional activities, so it is necessary to identify these difficulties and support teachers when putting them into practice in the classroom (Crujeiras \& Jiménez, 2015). Therefore, to guide secondary students through research learning, it is pertinent to promote professional competence in implementing this type of activity consistently with current educational approaches among teachers in training who are accustomed to traditional classes (Cruz-Guzmán et al., 2017; Donnelly et al., 2014). Other methodological approaches, such as classroom games, are unknown or are considered as a great challenge by many teachers, so their incorporation in teacher training is very useful to promote familiarity with them. Currently, they have begun to be introduced in various training courses, for both acting and future teachers (Annetta et al., 2014).

Ultimately, the approaches used in the classroom will be determined by the beliefs of the teaching staff, which is why studies are required that aim to change the conceptions of future teachers and reorient science teaching (Markic \& Eilks, 2008). A teacher training program should aim to hold preservice teachers' epistemic thinking (Erduran \& Kaya, 2019) and afford the necessary framework for developing epistemic beliefs due to the fact that teachers' epistemic beliefs impact on students' learning (Sosu \& Gray, 2012). The training of chemistry teachers must incorporate the development of skills for reflection on pedagogical practice (Gauche et al., 2007) so that, by experiencing approaches that are alternative to the traditional ones, explicit reflection on how we learn and teach is promoted. Identifying teachers' beliefs about teaching is beneficial in finding ways to change beliefs that are highly teacher-centred and focused on the content structure. Teacher training must influence this aspect by modelling constructivist teaching approaches oriented towards scientific literacy for all. For this, it is necessary 
to make teachers aware, through self-reflection, that their beliefs can influence their decisions and the actions they take (Markic et al., 2008). In this way, the teaching approach itself can become a learning object for future teachers (Abd-El-Khalick, 2012), and the practice itself a valuable tool in the educational design process as a source of inspiration (Prins et al., 2018). In addition, it is important to assume that future teachers will not spontaneously be able to integrate the content of the subject to be taught with pedagogical knowledge, so training programmes must have as a reference knowledge of desirable teaching, that is, teaching that is student-centred and based on learning through inquiry. It is therefore necessary for future teachers to have opportunities to put new teaching activities into practice and reflect on their results (Rivero et al., 2020). Thus, the incorporation of opportunities to reflect on the practical application of knowledge and skills allow PSTs to integrate the three crucial elements of theory, practice, and reflection (Kitchen \& Petrarca, 2016).

The design of new curricular materials, as well as the promotion of the adaptation and implementation of these approaches, can be useful to improve pedagogical knowledge of the content (Bayram-Jacobs et al., 2019). A programme that integrates activities in authentic teaching encourages the development of teaching knowledge of the content by requiring teachers in training to be able and willing to see the matter from the perspective of the students (Berry et al., 2016). Specifically, strategies for teacher training that include inquiry and modelling activities could promote the reorientation of the teaching approaches considered by future teachers (Schwarz \& Gwekwerere, 2007).

In the light of the above, to guide secondary education students through the different phases of inquiry and modelling learning, it is considered necessary that PSTs experience sequences of modelbased inquiry activities during their training as teachers that make sense to them. As well as making them reflect on what they learn and how they learn it, so that they are aware of the usefulness and effectiveness of these educational approaches, they will have examples of appropriate teaching practices that they can implement in their classes. The central core of an model-based inquiry sequence consists of posing an authentic problem and using evidence to draw conclusions, promoting both the learning and the interest and concentration of the students (Jiménez-Liso et al., 2020a). Thus, the implementation of inquiry and modelling teaching approaches in initial teacher training has been shown to lead future teachers to consider the inclusion of scientific practices as teaching activities in their professional future (Jimenez-Liso et al., 2019). In the study cited here, the authors implemented a modelbased inquiry sequence during teacher training to engage the PSTs with the question 'why is salt spread on the roads when it snows?'. The teachers in training acted as learners, by experiencing the learning of scientific content through scientific practices, and as thinkers, by reflecting on the conceptual and procedural content learned as well as on the emotions felt. Throughout the sequence, lasting 1 hour and 30 minutes, the teachers in training: 1) made predictions about the consequences for the temperature; 2) reflected on the usefulness of the particular kinetic model of matter to explain what happened; 3) designed experiments to collect the necessary data; and 4) reasoned from the data obtained to reformulate a new and more suitable model. In addition, most of the participants perceived themselves to have understood the fundamentals of scientific practice, experiencing positive emotions throughout.

In another study carried out by the López-Banet et al. (2021b), a model-based inquiry sequence on acid-base content was described that, through the use of $\mathrm{pH}$ meters, allowed students to explain and predict acidbase phenomena. In addition to the conceptual learning objectives, such as understanding the difference between dilution and neutralization, the sequence promoted the development of research skills, and helped students to be aware of the procedural knowledge they constructed. The sequence of activities included: 1) questions to enable the students to express, justify and discuss their ideas with different forms of communication, such as oral and written language, graphs and drawings; 2) the design of tests to contrast the initial ideas; 3 ) the analysis of results; and 4) the obtaining and discussion of conclusions about the results and the process followed. At the end, the need to use a model to explain the new phenomena was recognized, with the students required to make a proposal that was evaluated and reviewed by the whole group. Specifically, students were asked to draw pictures based on Lemery's historical model to help them explain the processes of acidity, basicity, and neutralization. The opportunity to create their own explanation allows them to dynamically connect experiment, model and reality, avoiding the idea that a model is a static reproduction. In addition, the implementation of the model-based inquiry sequence implied an interdisciplinary teaching approach, enriched by knowledge and skills in the various disciplines that constitute the STEAM field (science, technology, engineering, art and mathematics). PSTs showed differences regarding knowledge from before to after carrying out the sequence and significant relationships between the knowledge and their emotions (López-Banet et al., 2021a). This model-based inquiry sequence, together with the one previously described, can be considered as a suitable example for teacher training, which is why these sequences were incorporated as part of the present course programme, as will be discussed in the methodology section. 


\section{Aspects Related to the Design of Activities During Initial Training}

The inclusion of MBI approaches in secondary teacher training programmes allows PSTs to reflect and be aware of how scientific contents, both conceptual and procedural, are learned (Jimenez-Liso et al., 2019). Moreover, it is currently recognized that concepts of fundamental chemistry must be introduced, as these are needed to understand the social, economic and environmental problems that surround us, such as alternative energy or global warming. In fact, it is currently recommended that, instead of insisting on the explanation of phenomena, attention should be focused on teaching how chemists think and reason. In this way, it is possible to understand how this discipline has allowed humanity to interact more successfully with its environment, and to include discussion of the socioethical implications of chemical manipulation and the resolution of real problems in various areas (Talanquer, 2013). A US National Research Council report (NRC, 2003) highlights energy sources, environmental issues, life and medicine, and materials design as the top challenges.

According to Rivero et al. (2020), a desirable model for teaching knowledge in relation to content should highlight not only aspects of a conceptual nature, but also procedural and attitudinal ones. In addition, these aspects should be organized in maps that reflect the interdependent relationships between them and present relationships with problems that make sense for students and are relevant, both for the subject and for the professional and social context. The ScienceTechnology-Society (STS) strategy is considered to be a suitable mechanism for cultivating scientific literacy, when focused on situations in which science plays a prominent role. In these projects, contexts become the axis through which learning develops, establishing themselves as curricular content that is harmonized with a reflection on the nature of chemistry through approaches based on inquiry and modelling (Caamaño, 2018). Linking this content to those of other disciplines, by posing a current problem, allows real questions to be solved through the integration of knowledge from several fields (López-Banet et al., 2021b), with the contribution of teachers from different areas. Thus, the design of teaching units during teacher training encourages trainees' ideas to be taken into account, as well as allowing a critical analysis of directed laboratory practices (Rodríguez-Arteche \& Martínez-Aznar, 2018).

Moreover, gender equality is a fundamental human right, and one of the sustainable development goals (SDG) pursued by the United Nations (2020). According to UNESCO (2019), the presence of teachers specializing in science could improve girls' interest in STEM subjects, as well as making them more likely to choose a professional career in a STEM area. Chemistry teaching is in a privileged position for contributing to the achievement of this ODS goal from a perspective of inclusion, equality and diversity (Mehta et al., 2018). This aspect should be present in teacher training so that it is taken into account in the activities that teachers design during their training and in their professional future.

\section{RESEARCH QUESTIONS}

Considering the antecedents described, the purpose of this work is to evaluate the changes in the teaching epistemic beliefs of preservice teachers after a sequence of activities included in a student-centred approach training programme. To this end, the study focuses on two main questions:

What teaching knowledge presents preservice chemistry teachers after an initial training course?

How do preservice teachers' epistemic beliefs change after living scientific practices and game-based learning during the initial training course?

\section{RESEARCH METHOD}

\section{Research Context}

This study was developed during the academic year $2020 / 21$ as part of a course on chemistry education. The course was taught after the general pedagogical module of the Secondary Teacher Training Master's Degree, which is a requirement for teaching in secondary and baccalaureate education. Previously, the students had studied another course on general science education.

The course began with a questionnaire in which the trainees reflected on proposals to improve chemistry teaching. The content then started with a review of the models of teaching units based on the latest research in science education. The vast majority of this research focuses on contextualized teaching, the incorporation of classroom games, the development of scientific competence and the design of competency teaching units (Couso, 2013, Crujeiras et al., 2013; Franco \& Oliva, 2013; Franco-Mariscal et al., 2014; García et al., 2018). In addition, learning difficulties were discussed, the parts of a teaching sequence were analysed, and examples of activities were put into practice for the students to experience and reflect on instructional sequences that are looked on positively internationally for teaching chemistry (Jiménez-Liso et al., 2018). The students also attended seminars given by high school teachers on gamification. Parallel to the classroom sessions, the students freely formed three groups, with the exception of 1 student, to develop teaching units that they later presented to their classmates, with the intention that the way in which it met the needs of the models studied would be co-evaluated. The students worked cooperatively in the planning of the activities of the units, with the supervision, when necessary, of the 
teacher, who answered the questions that were raised. However, the design and structure of the teaching unit, including the contextualization in the legislative framework, content analysis, timing and description of the sessions was carried out individually in a portfolio that was delivered at the end of the subject, so 19 portfolios were collected, one per student. Everyone was free to organize the content in concept maps, selecting key ideas or questions, identifying types of content (conceptual, procedural or attitudinal), and identifying structuring notions and essential content, so that, depending on the analysis carried out, it was possible to identify the teaching models in relation to content. Finally, the students responded for the second time to the questionnaire on educational proposals for improving chemistry education.

\section{Research Tools}

In this study, a mixed model design that includes qualitative and quantitative analysis was used and it aimed to evaluate the change in the teaching epistemic beliefs of preservice teachers through their perceptions and their actions. Data collection was carried out through two instruments: a questionnaire, applied at the beginning and at the end of the course, to discover the changes in the beliefs of the students; and a coevaluation questionnaire. In addition, the teaching units on chemical changes worked on by the students during the course and the recording of the lessons were used to verify the triangulation of the results.

\section{Teaching Units Created by the PSTs}

Rivero et al. (2020) describe the progress of the teaching knowledge by analysing the type of content and the relationships between them, as well as with problems, cases or projects. The results provided by the bibliography usually described a model based on direct transmission of content, focused on the teacher and on the subject (M1), and another one (M4), regarding the construction of the content by the students and focused on learning. Nevertheless, two intermediate models (M3 and M4) emerged from data analysis (Rivero et al., 2020). The instrument described by these authors is based on the following four categories of analysis: types of content (conceptual, procedural and attitudinal) (TC), identification of essential content (CE), interactions between content (IC), and relationships between content and problems $(\mathrm{P})$. Four models that reflect a hypothesis of progression of teaching knowledge in relation to content were established:

- The first one consists of the direct transmission of content, through activities that address content of a conceptual nature or in practices of a procedural nature. In this model, all the content has the same value and it is organized in lists, but there is no problem that allows different parts of the content to be related.

- The second model, also of the transmissive type, highlights the content, conceptual and procedural, which is essential.

- In model 3, in addition to the above, the attitudinal content is also highlighted, and it is organized to show some interaction between different parts of the content and to relate the content to problems of a closed nature.

- Finally, the desirable teaching model would imply: 1) selecting a priori the different types of content in a balanced way (selecting those that are considered essential); 2) including maps that reflect the interdependence between the parts of the content; and 3) relating the content to open problems to be investigated that are meaningful for the students and relevant to the subject and to the professional context.

Additionally, the content knowledge of the 19 teaching units was analysed using the instrument included in Table 1 corresponding with the four models. The teaching units were designed during the course thus the models are identified exclusively at the end.

The contrast by pairs, in which each researcher classifies the teaching units according to the categories described in Table 1, obtained a coincidence of $67 \%$. The discrepancies between pairs were resolved, agreeing on the number of subjects found in each model of teaching knowledge.

\section{Co-evaluation of the Teaching Units}

Sanmartí (2007, p. 66) asked why teachers were the only ones qualified to detect mistakes and successes in student learning. For her, 'the students learn much more when they self-evaluate or are evaluated by their peers, than when teachers detect difficulties and propose changes'. The overall idea is that evaluation should be a three-way process, in which the student himself, with the help of the teacher and his classmates, is able to selfregulate his learning (Sanmartí, 2007, p. 67). With this reference, the teaching units were co-evaluated according to the framework discussed throughout the training course, which was focused on learning and based on content construction by students. The coevaluation was founded on four criteria: the adequacy of the activities, the planning of the activities, the degree of participation that the activities promote in the students, and the suitability of the material used. For each criterion the students indicated whether the teaching unit was (a) exceptional, (b) very good, (c) good, (d) acceptable or (e) questionable. Thus, the identified category was probably influenced by the teaching knowledge of the participants. Finally, they could suggest some improvements. 
Table 1. Hypothesis of the progression of teaching knowledge regarding contents (Rivero et al., 2020)

\begin{tabular}{|c|c|c|c|c|}
\hline Category & $\begin{array}{l}\text { Model 1: Direct } \\
\text { transmission of } \\
\text { content (M1) }\end{array}$ & $\begin{array}{l}\text { Model 2: Open } \\
\text { transmission of content } \\
\text { (M2) }\end{array}$ & Model 3: Problem solving (M3) & $\begin{array}{l}\text { Model 4: Construction of } \\
\text { content by students (M4) }\end{array}$ \\
\hline $\begin{array}{l}\text { Types of content } \\
\text { (TC) }\end{array}$ & $\begin{array}{l}\text { Conceptual content } \\
\text { or, in the case of } \\
\text { practical classes, } \\
\text { procedural content }\end{array}$ & & $\begin{array}{l}\text { Procedural and / or attitudinal } \\
\text { contents begin to be considered. } \\
\text { It is not done in a balanced way }\end{array}$ & $\begin{array}{l}\text { Conceptual, procedural } \\
\text { and attitudinal contents } \\
\text { are formulated in a } \\
\text { balanced way }\end{array}$ \\
\hline $\begin{array}{l}\text { Identification of } \\
\text { essential content } \\
\text { (CE) }\end{array}$ & $\begin{array}{l}\text { All content has the } \\
\text { same value }\end{array}$ & $\begin{array}{l}\text { Without arguing, essential } \\
\text { conceptual (theoretical } \\
\text { classes) or procedural } \\
\text { (practical classes) content } \\
\text { are highlighted }\end{array}$ & $\begin{array}{l}\text { Essential conceptual and } \\
\text { procedural content is highlighted }\end{array}$ & $\begin{array}{l}\text { Essential conceptual, } \\
\text { procedural and } \\
\text { attitudinal contents are } \\
\text { highlighted }\end{array}$ \\
\hline $\begin{array}{l}\text { Interactions } \\
\text { between contents } \\
\text { (IC) }\end{array}$ & $\begin{array}{l}\text { The contents are } \\
\text { s organized in lists or } \\
\text { in diagrams with } \\
\text { inclusion } \\
\text { relationships }\end{array}$ & & $\begin{array}{l}\text { The contents are organized on } \\
\text { maps with a certain degree of } \\
\text { interaction between them. } \\
\text { Inclusive interactions } \\
\text { predominate over } \\
\text { interdependence }\end{array}$ & $\begin{array}{l}\text { The contents are } \\
\text { organized in maps that } \\
\text { reflect systemic } \\
\text { relationships and } \\
\text { interdependence between } \\
\text { them }\end{array}$ \\
\hline $\begin{array}{l}\text { Relationship } \\
\text { between content } \\
\text { and problems, } \\
\text { cases or projects } \\
\text { (P) }\end{array}$ & $\begin{array}{l}\text { No problem, case or } \\
\text { project is formulated }\end{array}$ & & $\begin{array}{l}\text { The contents are related to } \\
\text { problems, cases or projects of a } \\
\text { closed nature }\end{array}$ & $\begin{array}{l}\text { All contents are related to } \\
\text { problems, cases or open } \\
\text { projects to investigate, } \\
\text { meaningful to students, } \\
\text { relevant to the subject and } \\
\text { to the professional / } \\
\text { social context }\end{array}$ \\
\hline
\end{tabular}

Table 2. Duration and methodology of the sessions carried out in the course

\begin{tabular}{lll}
\hline Session & Duration & Methodology \\
\hline 1 & $4 \mathrm{~h}$ & Inquiry activity on acid-base (López-Banet et al., 2021a) \\
2 & $4 \mathrm{~h}$ & Argumentation about climate change \\
3 & $4 \mathrm{~h}$ & Inquiry activities on the greenhouse effect and acid rain (Martínez-Carmona \& López-Banet, 2021) \\
4 & $4 \mathrm{~h}$ & Inquiry activity on COVID \\
5 & $4 \mathrm{~h}$ & Analysis of teaching units (Couso, 2013, Crujeiras et al., 2013; Franco-Mariscal et al., 2014; Franco \& Oliva, \\
& & 2013; García et al., 2018) \\
6 & $4 \mathrm{~h}$ & Analysis of gamification activities \\
7 & $2 \mathrm{~h}$ & Content types \\
8 & $2 \mathrm{~h}$ & Learning difficulties in learning chemistry \\
9 & $4 \mathrm{~h}$ & Salt-snow inquiry activity (Jimenez-Liso et al., 2021) \\
10 & $2 \mathrm{~h}$ & Assessment strategies \\
11 & $4 \mathrm{~h}$ & Oral presentation of the designed units \\
12 & $2 \mathrm{~h}$ & Course evaluation activity \\
\hline
\end{tabular}

\section{Questionnaire About the Students' Perceptions}

At the end of the previous year (2019/20), the students on this same course (ten women and nine men) prepared, openly and individually, a text with proposals for improvements in the teaching of chemistry. These texts were categorized into 20 items, and a 5-point Likert questionnaire ( 1 totally disagreeing and 5 totally agreeing) was created with them. The information analysed in the present investigation was collected using this questionnaire, which was validated by two experts. The purpose was for the students of the current course $(2020 / 21)$ to assess each of the items, both at the beginning and at the end of the course. The differences in the scores obtained, at the beginning and end of the course, established whether the teaching proposed throughout the course led to changes in the beliefs presented by the PSTs. The data were statistically treated with the SPSS 15.0 program using the Wilcoxon rank and sign test for dependent samples. The critical level of significance for the rejection of the null hypothesis was $\mathrm{p}<0.05$.

\section{Sample}

The student body that participated in this study consisted of 19 students (12 women and 7 men) with bachelor's degrees in chemistry (6), physics (6), biochemistry (5), chemical engineering (1) and food technology (1).

\section{Training Programme}

The course consisted of 40 hours of attendance, distributed in sessions of two or four hours (Table 2). The methodology used was fundamentally based on the 
Table 3. Teacher model demonstrates by PSTs

\begin{tabular}{lcccc} 
Model & $\begin{array}{c}\text { Types of content } \\
\text { (TC) }\end{array}$ & $\begin{array}{c}\text { Identification of } \\
\text { the essential content } \\
\text { (CE) }\end{array}$ & $\begin{array}{c}\text { Interactions within } \\
\text { content (IC) }\end{array}$ & $\begin{array}{c}\text { Relationship between } \\
\text { content and problems } \\
(\mathrm{P})\end{array}$ \\
\hline M1. Direct transmission of content & 8 & - & 5 & - \\
M2. Open transmission of content & - & 9 & - & - \\
M3. Problem solving & 6 & 8 & 12 & 19 \\
M4. Construction of content by students & 5 & 2 & 2 & - \\
\hline
\end{tabular}

student, and 85 of the 125 hours of work in the subject were used for private study by the student. During the course, PSTs develop the teaching knowledge needed to design adequate activities to be incorporated in a teaching unit. It consists of a basic unit of development of teaching where all decisions and curricular options are specified. It implies a commitment to active teaching, attention to the needs and interests of students and the search for meaningful content for students. In addition, a teaching unit is articulated around content axes that confer unity, reduce dispersion and facilitate the transfer of learning and functionality of what has been learned. To do this, it is made up of a series of differentiated activities that start from simple and concrete situations, while progressively reaching greater complexity and abstraction.

\section{RESULTS AND DISCUSSION}

\section{Analysis of the Teaching Units}

To answer the first question (What teaching knowledge present preservice chemistry teachers after an initial training course?) we analysed the 19 teaching units designed by the PSTs based on the methodology proposed by Rivero et al. (2020). Their characteristics are summarized in Table 3.

These results are similar to those described by Rivero et al. (2020), since most of the teaching units were based on problem solving. Thus, students designed a teaching unit located in the M3 model on interactions within the content (IC). Likewise, all the participants were able to relate content and problem (P) as M3 described. Nevertheless, regarding the types of content (TC) they were in M1, M3 and M4 and the identification of the essential content (CE) were distributed between M2, M3 and M4 models. According to these results, each student presents different models depending on the category. Thus, although most of them are closer to M4 than to M1, in terms of TC and CE some of them present teaching knowledge based on the transmission of content and focused on the subject.

It is considered that the models can be influenced by external factors such as the classroom context or chemistry problems when they start the practical period. At the end of the intervention, most of the participants diversified the types of content, relating them through concept maps in which inclusion relationships predominated. Likewise, the activities were contextualized and included the resolution of open problems (that give meaning to the learning of the content although not in their entirety), and for most of them the student-centred model prevailed. Some examples identified as M3, regarding the relationship between content and problems, included: activities to find out how hot air balloons work as a function of density; the properties of matter that affect the practice of certain sports; the proposal of experimental designs to avoid food oxidation; the verification of the effect of hydroalcoholic gel and soap on the SARS-CoV-2 virus; and plastic contamination. On the other hand, two of the teaching units were close to M4 as they began from the students' ideas to build up learning through the use of various resources, always related to problems relevant to the content to be taught. Some examples considered were the changes present in the environment or ScienceTechnology-Society context that promote the explicitness of ideas, as well as their sharing. However, because they did not present an open nature for investigation in all the activities, they were included in M3. Finally, M4 was considered with respect to the interactions between the contents (CI) in the cases in which the key questions of the teaching unit were interrelated, reflecting systemic relationships between the selected activities.

Regarding the second question (How do preservice teachers' epistemic beliefs change after living scientific practices and game-based learning during the initial training course?) two complementary methodologies were used: a questionnaire of students' opinions about the elements that improve the teaching of chemistry and the peers evaluation of the teaching units. The purpose of these two instruments is to examine the concordance between the elements that the students highlight in the questionnaire and those that they later value in the teaching units.

\section{PSTs' Beliefs About the Elements that Improve the Teaching of Chemistry}

Table 4 shows the progression of the perception of the PSTs about the essential elements that contribute to improving the teaching of chemistry. The data were collected at the beginning and end of the training process (pre- and post-test).

In the first place, it can be observed that, after taking several courses of the master's degree, PSTs began this course on the teaching of chemistry with certain ideas 
Table 4. Progression of PSTs' beliefs about the teaching and learning of chemistry

\begin{tabular}{|c|c|c|}
\hline Item & Pre-test & Post-test \\
\hline 1. Increase the number of laboratory / practical hours & 4.95 & $4.95^{\mathrm{a}}$ \\
\hline 2. Greater endowment of economic and human resources & 4.79 & $4.58 \mathrm{~b}$ \\
\hline 3. Encourage the development of small investigations & 4.11 & $4.74 \mathrm{c}^{*}$ \\
\hline 4. Expand the variety of spaces for science / visits to museums / chemical plants / university & 4.74 & $4.63 \mathrm{~b}$ \\
\hline 5. Contextualize the contents in close reality / motivation & 4.79 & $4.68^{b}$ \\
\hline 6. Quality preferable to quantity; reduction of the curriculum & 4.32 & $4.47 \mathrm{c}$ \\
\hline 7. Mathematics training & 4.89 & $4.74 \mathrm{~b}$ \\
\hline 8. Replace transmissive teaching in favour of teaching centred on the student body & 4.32 & $4.74^{\mathrm{c}}$ \\
\hline 9. Include the practice of argumentation & 4.53 & $4.84^{\mathrm{c}}$ \\
\hline 10. Promote collaborative teaching methodologies & 4.26 & $4.84^{\mathrm{c}}$ \\
\hline 11. Include a gender-balanced approach & 4.37 & $4.74^{\mathrm{c}}$ \\
\hline 12. Make visible the role of women in techno-scientific careers & 4.63 & $4.95 \mathrm{c}$ \\
\hline 13. Use model-based inquiry & 4.47 & $4.79 \mathrm{c}$ \\
\hline 14. Teachers in continuous training & 4.63 & $4.84^{\mathrm{c}}$ \\
\hline 15. Global, formative and evaluative evaluation methods & 4.63 & $4.79 \mathrm{c}$ \\
\hline 16. Decrease the ratio & 4.84 & $4.79 \mathrm{~b}$ \\
\hline 17. Provide some flexibility to the curriculum & 4.58 & $4.74^{\mathrm{c}}$ \\
\hline 18. Include more outreach activities & 4.74 & 4.74 a \\
\hline 19. Report career opportunities in science & 4.74 & $4.89 \mathrm{c}$ \\
\hline 20. Permanent state regulation & 4.89 & $5.00 \mathrm{c}$ \\
\hline
\end{tabular}

a No change

b Obtains lower evaluation in the final test

c Obtains higher evaluation in the final test

* Significant difference

about the changes that should take place in education to improve the teaching of science. The items with the highest values at the beginning were mostly detached from their own teaching work, such as increasing the number of laboratory / practical hours (1), an improvement in the mathematics foundation (7), a decrease in the ratio in class (16) and permanent state regulation (20). Therefore, in these first responses to the questionnaire there is not much reflection on how teachers themselves can improve learning in their classrooms. In contrast, the lowest values were given to encourage the development of small investigations (3) and collaborative teaching methodologies (10).

The implementation of the training course seems to have influenced these initial ideas, since in the final answers it was precisely the items related to teaching practice that obtained the greatest increase in the score. The assessment of conducting small investigations (5), a greater importance of quality over quantity (6), a student-centred education (8), the inclusion of argumentation (9), collaborative teaching (10), a genderbalanced approach (11), highlighting the role of women in science (12) and the incorporation of inquiry activities (13), improved in the questionnaire carried out at the end of the training. Of all of these, the realization of small investigations undergoes a significant change, although the incorporation of collaborative teaching and the gender approach are also close to achieving this. However, items that depend to a greater extent on external factors, such as increasing laboratory hours (1), economic resources (2), variation of spaces (4), training in mathematics (7) or a decrease in the ratio (16), are given a secondary role, since they decrease or maintain the values obtained at the beginning of the course.

\section{Co-evaluation of the Teaching Units}

The teaching units designed by the four groups were contextualized according to the following themes: 1) chemistry in the kitchen; 2) chemistry in everyday life; 3 ) chemistry and the environment and 4) trivial pursuit. These teaching units were analysed by all the classmates, and their answers are shown in Figure 1.

According to the co-evaluation, three of the four teaching units were well designed overall. Specifically, in the teaching units on chemistry in the kitchen, chemistry in daily life and trivial pursuit, 12 or more students rated the adequacy of the activities, the planning of the activities, the ability to promote

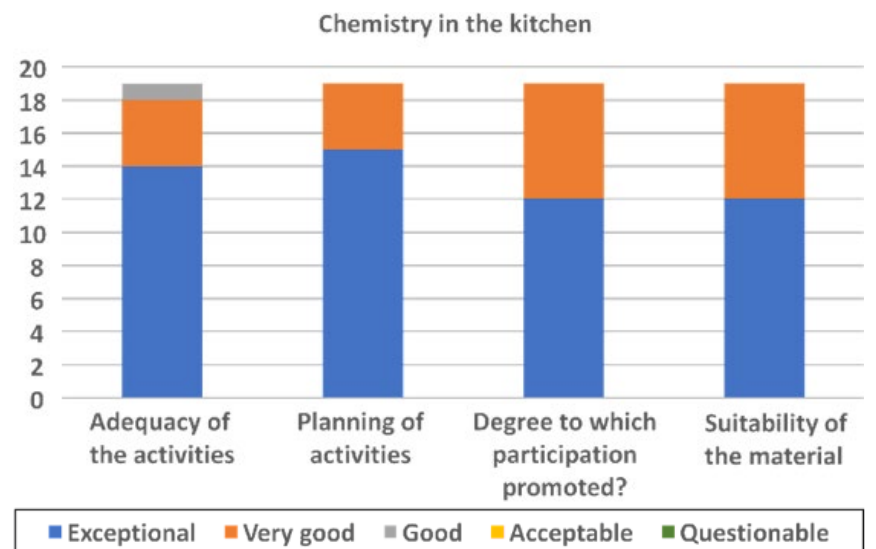

Figure 1. Results of the co-evaluation of the presentations given by the students (Data presented as individual punctuation) 
Chemistry in daily life

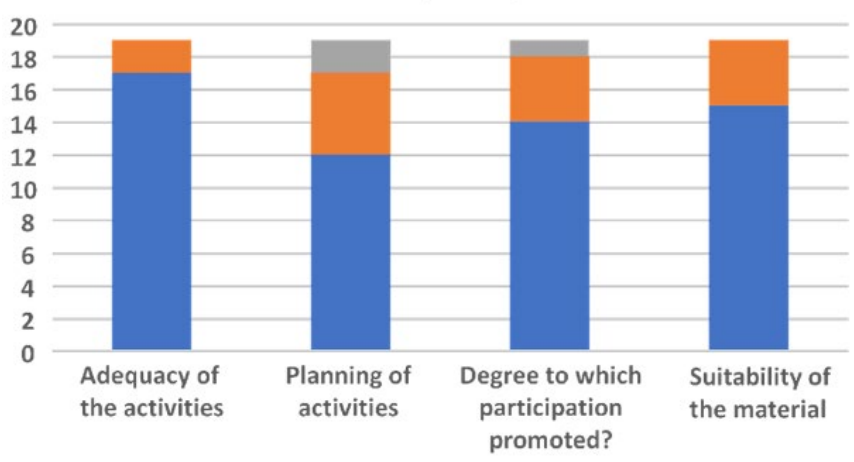

Chemistry and environment

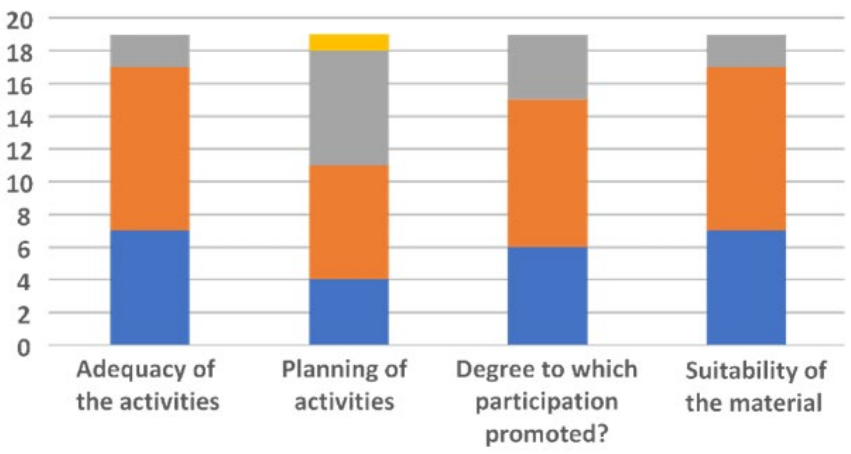

Trivial Pursuit

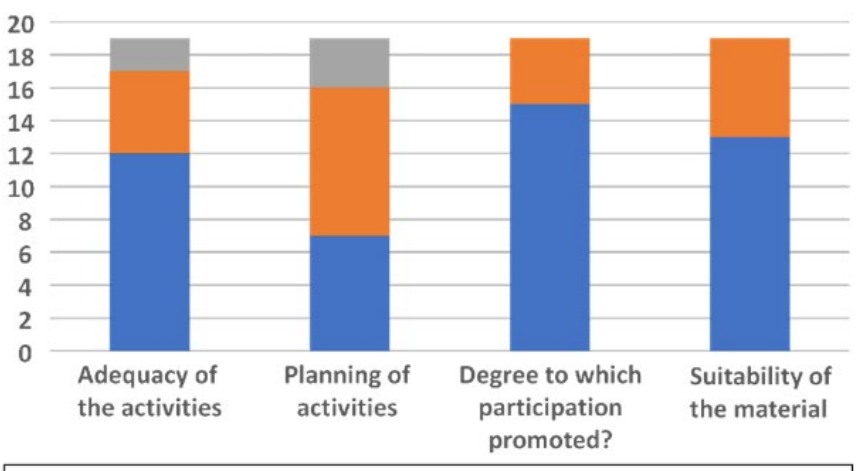

"Exceptional " Very good $\mid$ Good $=$ Acceptable " Questionable

Figure 1 (continued). Results of the co-evaluation of the presentations given by the students (Data presented as individual punctuation)

participation and the suitability of the materials as exceptional. However, the activity planning item in the trivial pursuit unit was lower. The rest of students valued these items mostly as very good. By contrast, at most 7 students gave this assessment to the teaching unit of chemistry in the environment, with a reasonable number of students (2-7) considering the items only to be good, and the qualification as 'acceptable' even appears for the planning of activities. The worst results were obtained in the Chemistry and environment teaching unit, prepared by a single student, which highlights the usefulness of group work in improving learning. Regarding the proposals for improvement made by the students, the following can be highlighted: 'In addition to answering the questions I would include more debates', 'The activities should be ordered in increasing order of difficulty', 'I would substitute some simulations for practical laboratory activities', 'I would better sequence the activities taking into account the phases of the teaching unit' and 'I would include some activity from a gender perspective'. These suggestions made by PSTs coincide with the elements of the questionnaire that experienced a greater increase in importance for them such as: a student-centred education (8), the assessment of conducting small investigations (5), the inclusion of argumentation (9) or a gender-balanced approach (11). Moreover, these answers show a reflection on how the knowledge acquired can be integrated in the design of activities for the teaching of chemistry and evidence PTSs have developed the teaching knowledge regarding the designing teaching units.

We agree with Franco-Mariscal et al. (2014) in the need for teachers to have a greater number of wellfounded teaching resources that serve as an example for the development of scientific competence in students. According to Talanquer (2013), this favours the organized teaching of content, respecting the characteristic foundations of chemistry. As Prins et al. (2018) state, practice in itself constitutes a valuable tool as a source of inspiration in the educational design process. This fact was affirmed by the participants and allowed the evaluation of the evolution of their teaching models based on the teaching units designed by them. We agree with Markic and Eilks (2008) and RodríguezArteche and Martínez-Aznar (2018), who stated that putting teaching into practice during chemistry teacher training contributes to changes in beliefs about science teaching and learning in line with the modern educational theory, helping to introduce improvements in teacher training programmes.

\section{CONCLUSIONS}

For the purpose of improving teacher training programmes, and in order that teaching can respond to the demands indicated by educational research, sequences of activities with a student-centred approach have been incorporated in the course, with the aim of inducing integrated learning of scientific content and teaching knowledge content, allowing a reflection on how science works. Experimenting, designing, and analysing activities and teaching sequences during teacher training is an innovative alternative for learning chemistry with meaning for students.

These approaches, put into practice during initial training, promote explicit reflection about how we learn and how we teach, turning the approach itself into an object of learning for future teachers. Therefore, the incorporation of scientific practices and model-games activities in the initial training of teachers allows them to experience these practices, reflecting explicitly on what they learn and how they learn it, and being aware of the usefulness of these educational approaches through 
activities that make sense for them. In addition, it is essential to promote inclusive education and the gender perspective at all educational levels, as well as in the training of future teachers.

The size of the sample is the main limitation of this research due to the maximum number of students enrolled in the training course. In addition, the practical period in secondary schools begins after this subject and it is not possible to reflect on the implementation of the teaching units. Thus, the prospects for the future would imply including aspects to improve the integration of theory, practice and reflection such as the teaching of the designed units. The application of teaching knowledge and skills within the school environment allows PSTs to contextualize them in the classroom as well as reflection on the real results of the teaching units probably modulates their epistemic beliefs.

Author contributions: All authors have sufficiently contributed to the study, and agreed with the results and conclusions.

Funding: This work has been partially financed by the project PGC2018-097988-A-I00 funded by FEDER/Ministry of Science and Innovation (MCI) of Spain- State Research Agency (AEI).

Declaration of interest: No conflict of interest is declared by authors.

\section{REFERENCES}

Abd-El-Khalick, F. (2012). Teaching with and about nature of science, and science teacher knowledge domains. Science and Education, 22(9), 2087-2107. https:/ / doi.org/10.1007/s11191-012-9520-2

Acevedo-Díaz, J. A., García-Carmona, A., \& Aragón, M. M. (2017). Historia de la ciencia para ensenar naturaleza de la ciencia: una estrategia para la formación inicial del profesorado de ciencia [History of science to teach nature of science: a strategy for the initial training of science teachers]. Educación Química, 28, 140-146. https:/ / doi.org/10.1016/j.eq.2016.12.003

Annetta, L., Lamb, R., Minogue, J., Folta, E., Holmes, S., Vallett, D., \& Cheng, R. (2014). Safe science classrooms: Teacher training through serious educational games. Information Sciences, 264, 61-74. https://doi.org/10.1016/j.ins.2013.10.028

Bayram-Jacobs, D., Henze, I., Evagorou, M., Shwartz, Y., Aschim, E. L., Alcaraz-Dominguez, S., Barajas, M., \& Dagan, E. (2019). Science teachers' pedagogical content knowledge development during enactment of socioscientific curriculum materials. Journal of Research in Science Teaching, 56(9), 1-27. https:/ / doi.org/10.1002/tea.21550

Bellová, R., Melichercíková, D., \& Tomcík, P. (2017). Possible reasons for low scientific literacy of slovak students in some natural science subjects. Research in Science \& Technological Education, 36(2), 226-242. https:/ / doi.org/10.1080/02635143.2017.1367656
Berry, A., Depaepe, F., \& Van Driel, J. (2016). Pedagogical content knowledge in teacher education. In J. Loughran, \& M. Hamilton (Eds.), International Handbook of Teacher Education, 1, 347386. Springer. https://doi.org/10.1007/978-98110-0366-0_9

Caamaño, A. (2018). Enseñar química en contexto: un recorrido por los proyectos de química en contexto desde la década de los 80 hasta la actualidad [Teaching chemistry in context: a tour of chemistry projects in context from the 1980s to today]. Educación Química, 29, 21-54. https://doi.org/ 10.22201/fq.18708404e.2018.1.63686

Christenson, N., \& Chang Rundgren, S. N. (2014). A framework for teachers' assessment of socioscientific argumentation: an example using the GMO issue. Journal of Biological Education, 49(2), 204-212. https:/ / doi.org/10.1080/00219266.2014.923486

Couso, D. (2013). La elaboración de unidades didácticas competenciales [The development of competency teaching units]. Alambique, 74, 12-24.

Crujeiras Pérez, B., \& Jiménez Aleixandre, M. P. (2018). Influencia de distintas estrategias de andamiaje para promover la participación del alumnado de secundaria en las prácticas científicas [Influence of different scaffolding strategies to promote the participation of secondary school students in scientific practices]. Enseñanza de las ciencias, 36(2), 23-42.

https:// doi.org/10.5565/rev/ensciencias.2241

Crujeiras, B., \& Jiménez, M. P. (2015). Desafíos planteados por las actividades abiertas de indagación en el laboratorio: articulación de conocimientos teóricos y prácticos en las prácticas científicas [Challenges posed by open inquiry activities in the laboratory: articulation of theoretical and practical knowledge in scientific practices]. Enseñanza de las Ciencias, 33(1), 63-84. https: / / doi.org/10.5565/rev/ensciencias.1469

Crujeiras, B., Jiménez Aleixandre, M. P., \& Gallástegui, J. R. (2013) Indagación en el laboratorio de Química. Secuencia de actividades en que el alumnado de $3^{\circ}$ y $4^{\circ}$ de ESO diseñan experimentos [Inquiry in the Chemistry laboratory. Sequence of activities in which 3rd and 4th ESO students design experiments]. Alambique, 74, 49-56.

Cruz-Guzmán, M., García-Carmona, A., \& Criado, A. M. (2017). An analysis of the questions proposed by elementary pre-service teachers when designing experimental activities as inquiry. International Journal of Science Education, 39(13), 1755-1774. https:/ / doi.org/10.1080/09500693.2017.1351649

Donnelly, D. F., McGarr, O., \& O'Reilly, J. (2014). 'Just be quiet and listen to exactly what he's saying': 
Conceptualising power relations in inquiryoriented classrooms. International Journal of Science Education, 36(12), 2029-2054. https://doi.org/ 10.1080/09500693.2014.889867

Erduran S., \& Kaya E. (2019). Epistemic Beliefs and Teacher Education. In: Transforming Teacher Education Through the Epistemic Core of Chemistry. Science: Philosophy, History and Education. Springer. https:/ / doi.org/10.1007/978-3-030-15326-7_3

Franco, A. J., \& Oliva, J. M. (2013). Diseño de una unidad didáctica sobre los elementos químicos [Design of a teaching unit on chemical elements]. Alambique, 74, 57-67.

Franco-Mariscal, A. J., Blanco-López, A., \& EspañaRamos, E. (2014). El desarrollo de la competencia científica en una unidad didáctica sobre la salud bucodental. Diseño y análisis de tareas [The development of scientific competence in a teaching unit on oral health. Task design and analysis]. Enseñanza de las Ciencias, 32(3), 649-667. https://doi.org/10.5565/rev/ensciencias.1346

García Martínez, N., García Martínez, S., Andreo Martínez, P., \& Almela Ruiz, L. (2018). Ciencia en la cocina. Una propuesta innovadora para enseñar Física y Química en educación secundaria [Science in the kitchen. An innovative proposal to teach Physics and Chemistry in secondary education]. Enseñanza de las Ciencias, 36(3), 179-198. https:/ / doi.org/10.5565/rev/ensciencias.2473

Gauche, R., Ribeiro da Silva, R., de Aguiar Baptista, J., Luiz Pereira dos Santos, W., de Souza Mól, G., \& Fernandes Lootens Machado, P. (2007). Formación de profesores de química: concepciones y propuestas [Chemistry teacher training: conceptions and proposals]. Educación Química, 18(1), 30-33. https:/ / doi.org/10.22201/fq.18708404 e.2007.1.65974

Jaber, L. Z., \& Hammer, D. (2016). Learning to feel like a scientist. Science Education, 100(2), 189-220. https://doi.org/10.1002/sce.21202

Jiménez-Liso, M. R., Gómez-Macario, H., MartínezChico, M., Garrido-Espeja, A., \& López-Gay LucioVillegas, R. (2020a). Egagrópilas como fuente de pruebas en una indagación. Percepciones de los estudiantes sobre lo que aprenden y sienten [Awls pellets as a source of evidence in an inquiry. Students' perceptions of what they learn and feel]. Revista Eureka sobre Enseñanza y Divulgación de las Ciencias, 17(1) 1203-16. https://doi.org/10.25267/ Rev_Eureka_ensen_divulg_cienc.2020.v17.i1.1203

Jiménez-Liso, M. R., López-Banet, L., \& Dillon, J. (2020b). Changing how we teach acid-base chemistry: A proposal grounded in studies of the history and nature of science education. Science $\mathcal{E}$ Education, 29, 1291-1315. https://doi.org/10.1007/s11191-02000142-6
Jimenez-Liso, M. R., Martinez Chico, M., Avraamidou, L., \& López-Gay Lucio-Villegas, R. (2019). Scientific practices in teacher education: the interplay of sense, sensors, and emotions. Research in Science and Technological Education, 39(1), 44-67. https:/ / doi.org/10.1080/02635143.2019.1647158

Jiménez-Liso, M. R., Martínez-Chico, M., \& SalmerónSánchez, E. (2018). Chewing gum and pH level of the mouth: a model-based inquiry sequence to promote scientific practices. World Journal of Chemical Education, 6(3), 113-116. https:/ / doi.org/10.12691/wjce-6-3-2

Kitchen J., \& Petrarca D. (2016). Approaches to teacher education. In J. Loughran, \& M. Hamilton (Eds.), International Handbook of Teacher Education. Springer. $\quad$ https://doi.org/10.1007/978-981-100366-0_4

Lantz, O., \& Kass, H. (1987). Chemistry teachers' functional paradigms. Science Education, 71, 117134. https:/ / doi.org/10.1002/ sce.3730710114

López, V., \& Domenech-Casal, J. (2018). Juegos y gamificación en las clases de ciencia: ¿una oportunidad para hacer mejor clase o para hacer mejor ciencia? [Games and gamification in science classes: an opportunity to do better class or to do better science?]. Ludus Scientiae, 2(1), 34-44. https:/ / doi.org/10.30691/relus.v2i1.1059

López-Banet, L., Aguilera, D., Jiménez-Liso, M. R., \& Perales-Palacios, F. J. (2021a). Emotional and cognitive preservice science teachers' engagement while living a model-based inquiry science technology engineering mathematics sequence about acid-base. Frontiers in Psychology, 12, 1-9. https:/ / doi.org/10.3389/fpsyg.2021.719648

López-Banet, L., Perales, F. J., \& Jimenez-Liso, M. R. (2021b). STEAM views from a need: the case of the chewing gum and $\mathrm{pH}$ sensopill. Journal for the Study of Education and Development, 44(4), 909-941. https:/ / doi.org/10.1080/02103702.2021.1927505

López-Banet, L., Ruiz González, C., \& Ayuso Fernández, E. (2020). Relationships between knowledge, attitudes and interests of Spanish pre-university students in relation to different areas of biotechnology. Eurasia Journal of Mathematics, Science and Technology Education, 16(12), em1916. https: / / doi.org/10.29333/ ejmste/9158

Markic, S., \& Eilks, I. (2008). A case study on German first year chemistry student teachers' beliefs about chemistry teaching, and their comparison with student teachers from other science teaching domains. Chemistry Education Research and Practice, 9, 25-34. https:/ / doi.org/10.1039/B801288C

Markic, S., Eilks, I., \& Valanides, N. (2008). Developing a tool to evaluate differences in beliefs about science teaching and learning among freshman science 
student teachers from different science teaching domains: a case study. Eurasia Journal of Mathematics, Science \& Technology Education, 4(2), 109-120. https:/ / doi.org/10.12973/ejmste/75311

Martínez-Chico, M., López-Gay Lucio-Villegas, R., \& Jiménez-Liso, M. R. (2014). La indagación en las propuestas de formación inicial de maestros: análisis de entrevistas a formadores de Didáctica de las Ciencias Experimentales [The inquiry into the initial teacher training proposals: analysis of interviews with trainers of Didactics of Experimental Sciences]. Enseñanza de las Ciencias, 32(3), 591-608. https://doi.org/10.5565/rev/ ensciencias.1376

Martínez-Carmona, M., \& López-Banet, L. (2021). Unidad didáctica sobre los cambios químicos que intervienen en el efecto invernadero [Didactic unit on the chemical changes involved in the greenhouse effect]. Ápice. Revista de Educación Científica, 5(2).

Mehta, G., Yam, V. W. W., Krief, A., Hopf, H., \& Matlin, S. A. (2018). The chemical sciences and equality, diversity, and inclusion. Angewandte ChemieInternational Edition, 57(45), 14690-14698. https:/ / doi.org/10.1002/anie.201802038

National Research Council (NRC) (2003). Beyond the molecular frontier: challenges for chemistry and chemical engineering. National Academy Press

Prins, G. T., Bulte, A. M. W., \& Pilot, A. (2018). Designing context-based teaching materials by transforming authentic scientific modelling practices in chemistry. International Journal of Science Education, 40(10), 1108-1135. https://doi.org/10.1080/ 09500693.2018.1470347

Rivero, A., Hamed, S., Delord, G., \& Porlán, R. (2020). Las concepciones de docentes universitarios de ciencias sobre los contenidos [The conceptions of university science teachers about the contents]. Enseñanza de las Ciencias, 38(3), 15-35. https:/ / doi.org/10.5565/rev/ensciencias.2845

Rodríguez-Arteche, I., \& Martínez-Aznar, M. M. (2018) Evaluación de una propuesta para la formación inicial del profesorado de Física y Química a través del cambio en las creencias de los participantes [Evaluation of a proposal for the initial training of physics and chemistry teachers through the change in the beliefs of the participants]. Revista Eureka sobre Enseñanza y Divulgación de las Ciencias, 15(1), 1601. https://doi.org/10.25267/Rev_Eureka_ ensen_divulg_cienc.2018.v15.i1.1601

Sanmartí, N. (2007). 10 ideas clave. Evaluar para aprender [10 key ideas. Assess to learn]. Graó.

Schwarz, C.V., \& Gwekwerere, Y. N. (2007). Using a guided inquiry and modeling instructional framework (EIMA) to support preservice K-8 science teaching. Science Education, 91, 158-186. https://doi.org/10.1002/sce.20177

Sosu, E. M., \& Gray, D. S. (2012). Investigating change in epistemic beliefs: An evaluation of the impact of student teachers' beliefs on instructional preference and teaching competence. International Journal of Educational Research, 53, 80-92. https:// doi.org/10.1016/j.ijer.2012.02.002

Talanquer, V. (2013). School chemistry: The need for transgression. Science and Education, 22, 1757-1773. https: / / doi.org/10.1007/s11191-011-9392-x

UNESCO (2019). Descifrar el código: la educación de las niñas y las mujeres en ciencias, tecnología, ingeniería y matemáticas (STEM) [Cracking the code: girls' and women's education in Science, Technology, Engineering, and Mathematics (STEM)]. https:// unesdoc.unesco.org/ark:/48223/pf0000366649

United Nations (2020). Objetivos de desarrollo sostenible [Sustainable development goals]. https:/ / www.un .org/sustainabledevelopment/es/gender-equality

Vázquez-Alonso, A., \& Manassero-Mas, M. A. (2016). Juegos para enseñar la naturaleza del conocimiento científico y tecnológico [Games to teach the nature of scientific and technological knowledge]. Educar, 53(1), 149-170. https://doi.org/10.5565/rev/ educar.839

Zidny, R., Ningtias Laraswati, A., \& Eilks, I. (2021). A case study on students' application of chemical concepts and use of arguments in teaching on the sustainability-oriented chemistry issue of pesticides use under inclusion of different scientific worldviews. EURASIA Journal of Mathematics, Science and Technology Education, 17(7), em1981. https://doi.org/10.29333/ ejmste/10979

\section{http://www.ejmste.com}

